Bohma S.D., PhD student SHEI «The Ukrainian Academy of Banking of the NBU», Ukraine, Sumy

\title{
INFORMATION DISCLOSURE STANDARD ON REAL BANK OWNERS AND CORPORATE STRUCTURE
}

\section{Summary}

The article is devoted to the research of consolidation processes in the banking system of Ukraine and the problem of banks ' non-disclosure of complete information about ownership structure and corporate structure. On the ground of normative statements of international authorities on banking supervision, methodology of rating agencies and domestic normative documents the standard of information disclosure is developed. The standard is aimed at orientation banks to disclose information about its end owners and corporate structure.

Key words: bank consolidation, property structure, corporate structure, information disclosure standard.

\section{Introduction}

Today there are a lot of barriers in the banking system of Ukraine that can't allow building complete and open picture of consolidation processes with banks ' participation. The dominance of implicit consolidation in domestic banking sector is inseparably linked with the problem of non-disclosure of information about real bank owners in Ukraine. Such situation does not give an opportunity to determine real level of consolidation processes between banks and mark out certain groups of banks which are connected by one owner, same strategy etc. According to the above and the requirements of international authorities in regulation of bank activity, the necessity of implementation of information disclosure standard becomes topical. This standard will be aimed at orienting banks to disclose the information about real owners of the bank and its corporate structure.

\section{Formulation of the problem}

The objective of the article is to investigate the problem of banks' non-disclosure of information about them and their activity and to develop standard that is aimed at orienting banks to information disclosure about end owners and corporate structure. 


\section{Results}

Nowadays in world practice much attention is being paid to the question of transparency of banks' activity on the financial markets. Basel Committee on banking supervision has developed many normative documents which concern the question of information disclosure about bank activity and its transparency on the financial markets [1]. These documents contain six categories of information, which should be completely and clearly provided by banks to reach the necessary level of its transparency:

- financial performance;

- financial position (including capital, solvency and liquidity);

- risk management strategies and practices;

- risk exposures (including credit risk, market risk, liquidity risk, and operational, legal and other risks);

- accounting policies;

- basic business, management and corporate governance information.

According to these categories Basel Committee on banking supervision recommends banks to provide exhaustive information. Market discipline can only work if there is a presence of reliable and true information about banks' activity. Improved public disclosure may attain development and financial stability of the banking system of the country.

However, disclosure alone does not necessarily result in transparency. To achieve transparency, a bank must provide timely, accurate and sufficient disclosures of qualitative and quantitative information that can be used in assessment of bank's activity and risk profile.

The main normative document of international authority on banking supervision in this matter is «Enhancing Bank Transparency» of 1998 [1]. It provides an accurate description of mentioned categories of information which should be disclosed by banks, and recommendations to improve transparency of bank activity. This statement comes forward as a manual for national bank regulatory bodies in the line of improving the domestically level of bank transparency. Meanwhile, there is a separate information block in this statement concerning disclosure of ownership structure and shareholders of the bank.

The basic information about activity, management and corporate governance in the bank, which is recommended by Basel Committee on banking supervision for disclosure by banking institutions, is presented in figure 1 . 


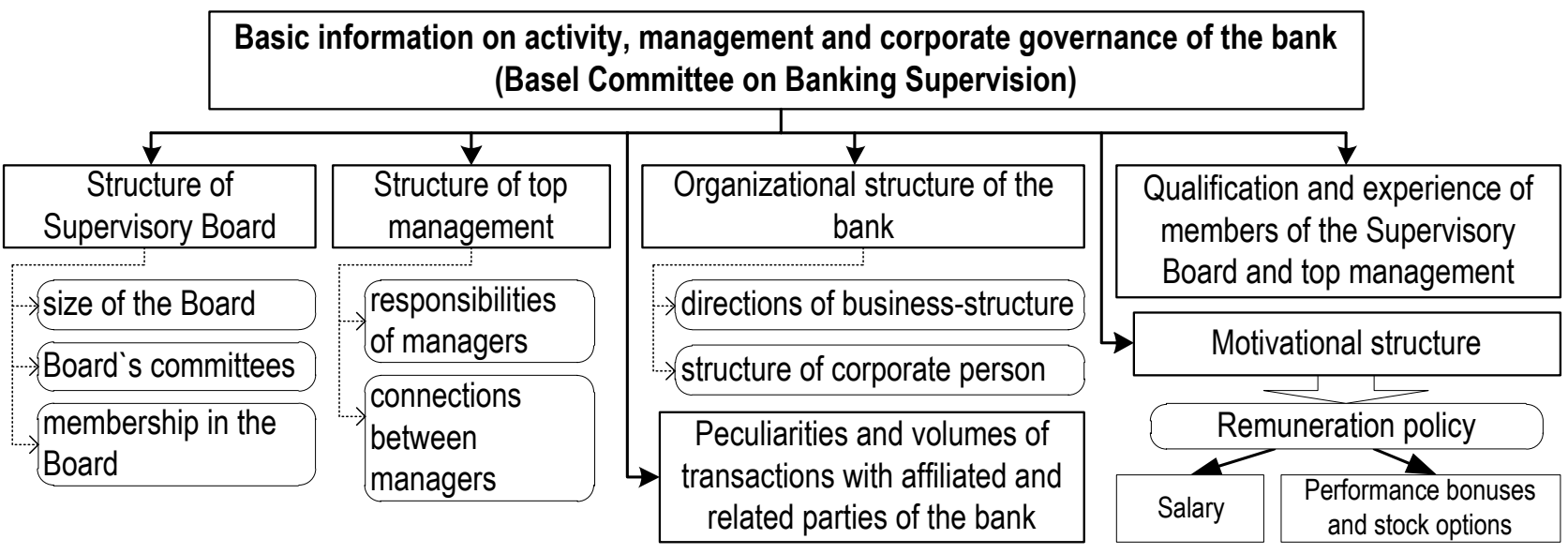

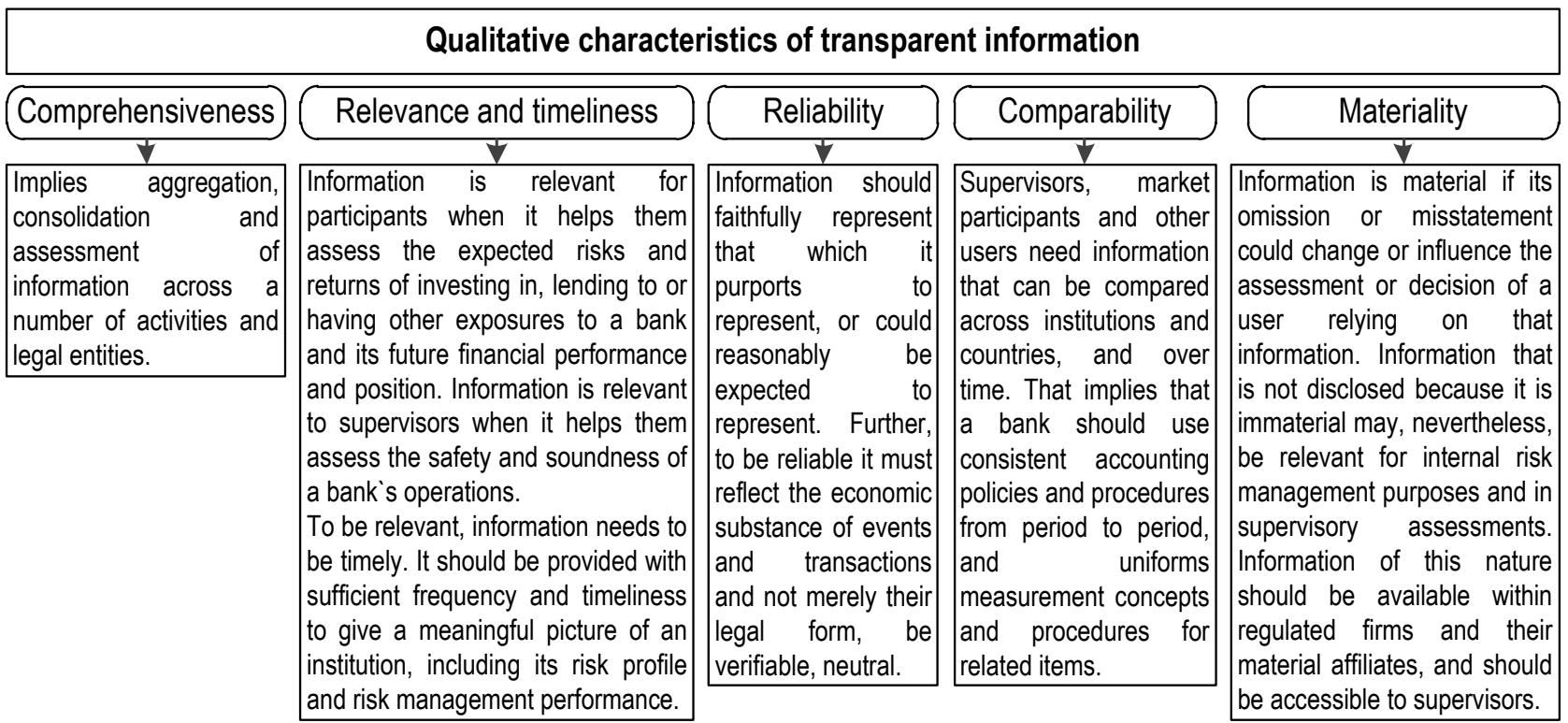

\section{Figure 1. Basic information on activity, management and corporate governance of the bank (Basel Committee on banking supervision) [1])}

As we can see from the figure 1, the marked information block discloses all the necessary information about corporate structure and ownership structure of the bank. Therewith the Basel Committee on banking supervision provides the list of qualitative characteristics of transparent information.

Meanwhile, in statement we can find the benefits of information disclosure for banking system both on macrolevel and microlevel. In such way international authorities on banking regulation and supervision try to emphasize the importance and necessity of complete disclosure of information by banks.

Therefore, the main benefits of information disclosure by banks on micro- and macrolevel are:

- an opportunity for banks to enter financial markets more efficiently than bank-competitors which do not disclose information about their activity and ownership structure;

- sound and well-managed bank is able to attain better terms and conditions in transactions with informed and rationally-behaving market counterparties; 
- depositors of bank are more confident when they know that their money are in the institution with clear ownership structure. In addition that indicates the high level of financial stability and reliability of bank on the banking services market;

- market can refuse to enter into a new business with an unsound bank on any terms in consideration of lack of information about real bank owners;

- market disruptions are likely to be greater if the flow of information is irregular, with long periods of good or no news and sudden releases of negative information. If disclosure is ongoing, the mechanisms of market discipline can work earlier and more efficiently. Timely public disclosure can reduce the severity of market disturbances. That is because market participants are informed on a more ongoing basis and therefore not as likely to overreact to information about current conditions;

- public disclosure of information can also help limit the systemic effects of market disruptions by increasing the ability of the market in times of stress to distinguish those banks that are vulnerable from those that are not;

- adequate public disclosure facilitates a more efficient allocation of capital between banks since it helps the market accurately assess and compare the risk and return prospects of individual banks [1].

Thus, we can consider that on the international level supervisory bodies have developed the necessary information disclosure requirements for banks. An individual part of information is the information concerning corporate structure and ownership structure of the bank. Statements, which are developed by Basel Committee on banking supervision, come forward as the foundation for corresponding authorities on the national level to regulate public disclosure of information about the bank. This information should be accessible and clear for market participants and supervisory bodies particularly.

It should be noted that the National Bank of Ukraine has developed the Statement «On the order of provision information about ownership structure» No 306 of September 8, 2011 [2]. The Statement partly meets normative documents of Basel Committee concerning disclosure of information about bank and its activity on financial markets. Thus, the Statement determines the order of bank's provision of information about ownership structure, associate companies and other parties that can indirectly control and own substantial part in the bank.

General characteristics of main parts of the Statement are presented in table 1.

Comparing this Statement with international documents concerning improvement of information disclosure about activity of bank and its ownership structure, we can mark out that the Statement of the NBU determines certain parts, which describe requirements on transparency of information about bank and its disclosure in public sources.

According to the normative document of the NBU, ownership structure of the party may be considered as transparent if provided to the NBU and placed on the website of the bank information allows determining participants that have direct / indirect substantial part in the bank. Additionally, relations between participants are also taken into consideration [3]. But in practice we observe the situation when ownership structure of he bank is not transparent enough to determine its real owners. 
Table 1. Characteristics of main parts of the Statement «On the order of provision information about ownership structure» [2]

\begin{tabular}{|c|c|}
\hline Part of the Statement & Short characteristics \\
\hline 1. Generalities. & $\begin{array}{l}\text { A part presents main terms and definitions which are used in the Statement; } \\
\text { conditions of provision the information about ownership structure of asso- } \\
\text { ciate companies and parties, which are connected with indirect ownership } \\
\text { and / or controlling the substantial part in bank, are presented; an order of } \\
\text { estimation of the size of party`s participation in bank under different condi- } \\
\text { tions of ownership with substantial part in bank and / or possibility of hav- } \\
\text { ing decisive influence on management or activity of the bank is provided; } \\
\text { definitions of direct and indirect ownership of substantial part in bank are } \\
\text { given; conditions of transparency of information about ownership structure } \\
\text { of the party or a bank are described; requirements on provision of informa- } \\
\text { tion about ownership structure of bank and means of influence when violat- } \\
\text { ing requirements of the Statement are determined. }\end{array}$ \\
\hline $\begin{array}{l}\text { 2. Order of provis } \\
\text { the information ab } \\
\text { ownership structure }\end{array}$ & $\begin{array}{l}\text { A part determines blocks of information, which must be provided to the } \\
\text { NBU, concerning an individual that is going to start banking activity or } \\
\text { get or increase substantial part in bank; the list of details and signatures } \\
\text { which should be presented in individual's data is given; the content and } \\
\text { structure of forms, which are presented to the NBU by individuals, are } \\
\text { given; requirements to execution of documents, which are affiling ac- } \\
\text { cording to the Statement, and terms of providing information about } \\
\text { presence / absence of parties, that have direct relation to substantial part } \\
\text { in bank and decisive influence on its activity, are determined; require- } \\
\text { ments to schematic representation of bank`s ownership structure and its } \\
\text { sending to the NBU are determined; the possibility of the NBU to re- } \\
\text { ceive confidential data about bank and its owners from state bodies and } \\
\text { other parties is pointed out. }\end{array}$ \\
\hline $\begin{array}{l}\text { 3. Placement of infor- } \\
\text { mation about owners of } \\
\text { substantial part on the } \\
\text { website of the bank }\end{array}$ & $\begin{array}{l}\text { Requirements on placement and updating information about owners of sub- } \\
\text { stantial part in bank under certain form on the website of the bank, including } \\
\text { examples, are determined; it is noticed that information on the website of the } \\
\text { bank should be free of charge for all interested parties of the bank. }\end{array}$ \\
\hline
\end{tabular}

Despite the existing normative supply in Ukrainian banking practice concerning disclosure of information about ownership structure in the bank and partly fulfillment of requirements of international supervisory authorities, not all of the banks provide complete information about real owners and corporate structure. This situation once again shows an urgency and necessity of accessing information about the real ownership structure of the bank which can be useful both for supervisory bodies and bank clients. The results of official investigations of information transparency of banks made by rating agencies every year confirm an indicated problem.

Since 2006 the Agency of Financial Initiatives and Standard \& Poor's have made an analysis of information transparency of banks. It should be noted that there is an upward tendency to increase of information transparency of banks in Ukraine during 2006-2013. Over this period of time the middle level of information disclosure by banks has increased from $42 \%$ to $56,58 \%$ [4-10]. 
An investigation is based on methodology which is developed by the Service of corporate governance ratings of the Standard \& Poor`s [11]. The questionnaire consists of three blocks with different amount of points from year to year:

- Information Block 1 «Ownership structure and rights of shareholders»;

- Information Block 2 «Financial and operational information»;

- Information Block 3 «Staff and procedures of Supervisory Board and management».

Methodology of agency uses public information during the investigations. The main sources of information are: annual reports, websites of banks, statements for supervisory bodies which provide it in open access: the NBU, the NSSMC, stock exchanges et al. It should be noted that official websites of banks provide the most complete information of all three blocks which are analyzed by Standard \& Poor's.

Information Block 1 includes many criteria of investigation. Those of them, which are connected with investigation of consolidation processes and information disclosure about bank owners or parties that have concentrated managerial decisionmaking, are the follows:

- the largest owner;

- information about shareholders;

- holdings of shares, which belong to certain members of Supervisory Board;

- holdings of shares, which belong to certain members of the Board of Administration;

- type structure of shareholders;

- percentage of cross-shareholding;

- information about indirect ownership;

- the list of affiliated companies (bank possesses 5-50\% of shares);

- the list of subsidiaries (bank possesses more than $50 \%$ of shares);

- ownership structure of affiliated companies and subsidiaries;

- information about other associated companies (general relatives, managers, mutual ownership of assets et al.).

According to the results of investigation, banks provide the most complete information about ownership structure and rights of shareholders. But among all of 30 analyzed banks the information disclosure on this block varies from $28 \%$ to $86 \%$. It tells us about the problem of non-disclosure of complete information about bank owners and corporate structure.

It should be observed that banks disclose quite complete information about the amount, classes and rate of ordinary shares, description of classes of shares; information about shareholders, which have large holding of shares (more than 10 percent); information about last corporate events published as press releases on websites of the banks. Information about appurtenance of shares by certain members of the Supervisory Board is disclosed a little bit worse. The information about the last meeting of shareholders, which is presented as a list of events about the fact of its holding, is presented poorly too. Disclosure of the content of Codes of corporate governance and ethics is still on a low level, while the information concerning cross-shareholding and 
noted level of dividends is practically unpublished. As we can see, a lot of criteria in the analyzed block of information are still on a low level of disclosure. Therewith, the identification of perimeter of group consolidation of the bank is still an open question. That is an additional proof of prevalence of implicit consolidation processes in the banking system of Ukraine [11].

In this block a lot of attention is also paid to investigation of transparency of information about end owners. As we can see from the last researches, the concentration of ownership in the banking system of Ukraine stays on the high level - the share of one shareholder, that owns more than $75 \%$ of stock capital, is about $70 \%$ of the sample. But it doesn't have significant influence on information disclosure about real owners. In this case it is the banks with foreign capital of large international companies that provide the most complete information about owners. State banks and banks with direct owners-individuals are the banks which disclose their real owners too. Others publish information only about direct formal owners which are little-known companies.

In confirmation of previous words we can find information about owners of banks which is published on the official website of the NBU in the part «Bank supervision» - «Information about owners of large holdings of shares in bank». This subdivision appeared recently and was stimulated by adopting the Law of Ukraine «On the making alteration in some laws of Ukraine concerning regulation of activity of banks» [12], which was consummated on 16 June 2011. According to the mentioned changes concerning banks in Ukraine there is an obligatory condition that banks should disclose information about the ownership structure and owners of large holdings in the bank. There is no doubt that these actions of the NBU are aimed at improvement of domestic legislation in banking sphere and forthcoming to the international practice. Unfortunately, although the accepted statement of the NBU, which provides obligatoriness of information disclosure about ownership structure and owners of large holdings, access of data about real owners from banks has not been reached yet. Instead of that, as was mentioned above, banks in the role of their owners mark little-known companies or international companies, which are registered in offshore zones, which in many cases have Ukrainian stock capital.

According to the above, we consider that it is reasonable, on the ground of existing laws and regulatory statements of the NBU, international documents and recommendations of banking supervisory bodies, methodology of rating agencies, to develop a standard, which will be used by banks as a guideline for information disclosure about real owners of bank and its corporate structure.

This standard consists of some parts, in which a lot of attention is mainly paid to formation of requirements to banks concerning information disclosure about the real owners of institution. Ex facte, the second part of the standard of description of corporate structure, staff of Supervisory Board, management and its activity and makingdecision procedures has no relation to bank's disclosure of information about ownership structure. But top management along with owners can have sufficient influence on activity of bank and making important decisions concerning strategy of bank`s activity in the financial markets. From the aspect of investigation of consolidation proc- 
esses in the banking system of Ukraine such information is very important. Because in order to receive complete picture of state of bank consolidation in the country it is necessary to possess the information both on famous bank owners in fact and individuals, who can make important management decisions.

The description of main information blocks of developed Standard is imaged on the figure 2 .

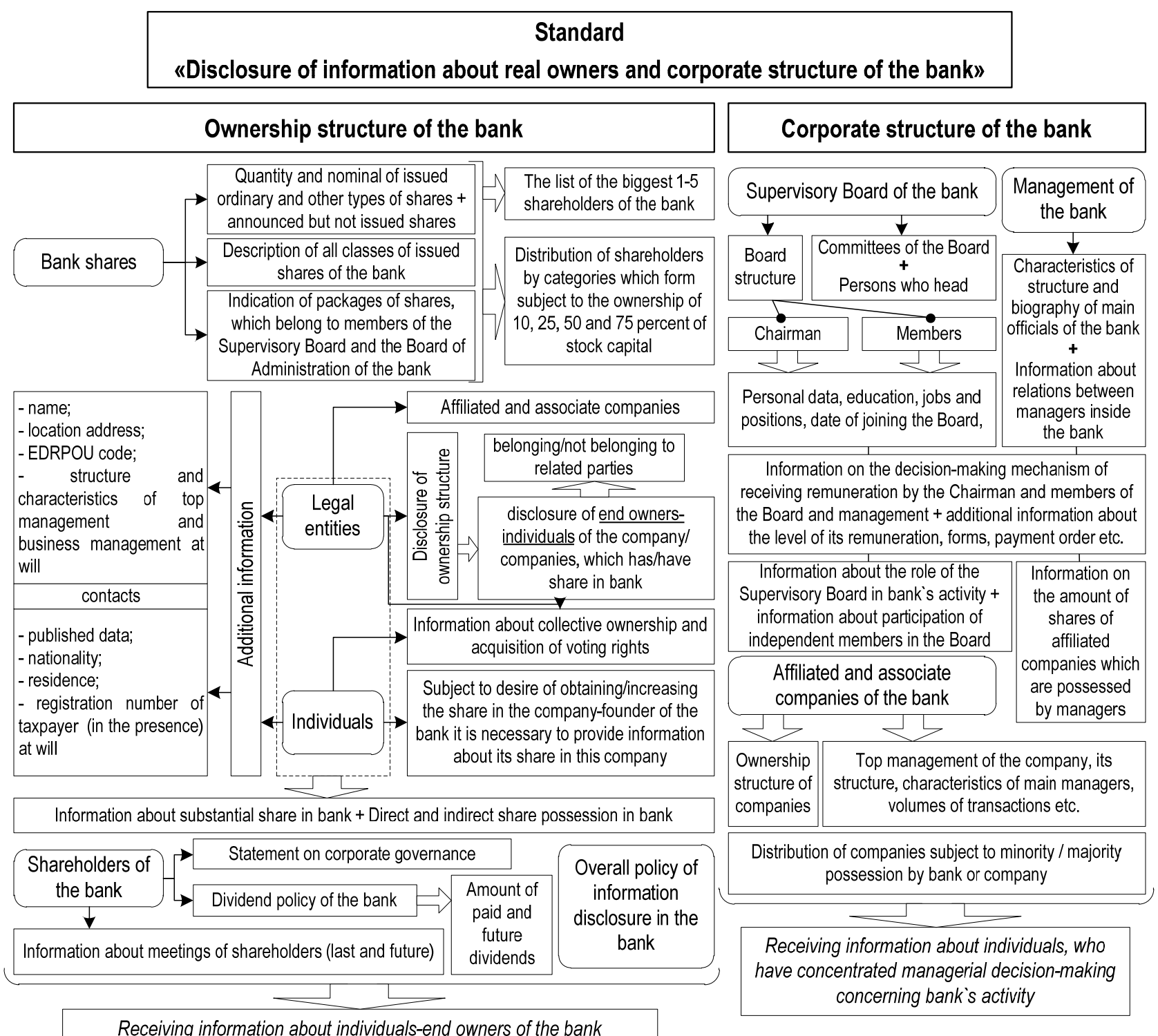

\section{Figure 2 - Main information blocks of the Standard «Disclosure of information about real owners and corporate structure of the bank» (developed by author on the base of $[1,2,11,13-15]$ )}

Thereby, the developed standard contains all the necessary information, which should be provided by banks to disclosure of their real owners. 


\section{Conclusion}

It should be noted that this standard does not contain some list of penalties and procedures that can be applied to the bank if it refuses to disclose complete information about ownership structure. In this case banks should realize the necessity of such information disclosure by themselves. There is no doubt that the best solution of the problem of non-disclosure of complete information about bank owners is providing this information on a voluntary basis and not under pressure of international bodies on regulation of bank activity or the NBU. But in consideration of difficulties of realization this variant at first, for all that the most appropriate and effective is to stimulate banks to disclose mentioned information by the state regulator of banking system and other parties.

\section{Literature}

1. Enhancing Bank Transparency [Electronic source] / Basel Committee on Banking Supervision // Monetary \& financial stability. - 1998. - Access mode: http://www.bis.org/publ/bcbs41.pdf.

2. Про порядок подання відомостей про структуру власності [Електронний ресурс] : постанова НБУ від 08.09.2011 № 306. - Режим доступу: http://zakon.nau.ua/doc/?uid=1201.1333.0.

3. Офіційний Інтернет-сайт Національного банку України [Електронний pecypc] / Економічні матеріали. - Режим доступу: http://bank.gov.ua.

4. $\mathrm{S} \& \mathrm{P}$ публикует первые исследования информационной прозрачности и корпоративного управления в украинских банках [Электронный реcypc] / Standard \& Poor's // «Bankir.ru». - Режим доступа: http://bankir.ru/.

5. $\mathrm{S} \& \mathrm{P}$ заявляет об отсутствии тенденций к улучшению информационной прозрачности банковского сектора Украины [Электронный ресурс] / «Украинские Новости». - Режим доступа: http://www.cbonds.info/.

6. S\&P: Уровень прозрачности крупнейших украинских банков в 2007 г. снизился [Электронный ресурс] / «Интерфакс-Украина» // «Finance.ua» - Режим доступа: http://news.finance.ua/.

7. Standard \& Poor's отмечает рост прозрачности банков Украины на фоне падения доверия инвесторов [Электронный ресурс] / Standard \& Poor's // «Bankir.ru». - Режим доступа: http://bankir.ru/.

8. Украинские банки имеют недостаточный уровень публичного раскрытия информации [Электронный ресурс] / Информационное агентство ЛІГАБізнесІнформ. - Режим доступа: http://news.liga.net/.

9. Исследование информационной прозрачности банков Украины 2012 год [Электронный pecypc] // (UCRA). - Режим доступа: http://www.ucra.com.ua. 
10. Исследование информационной прозрачности банков Украины 2011 год [Электронный ресурс] / «Кредит-Рейтинг». - Режим доступа: http://www.credit-rating.ua/ru/about/project/13050/.

11. Исследование информационной прозрачности банков Украины в 20092010 г. [Электронный pecypc] / Standard \& Poor's, Агентство финансовых инициатив, USAID Capital Markets Project // Capital Markets Project. - Режим доступа: http://www.capitalmarkets.kiev.ua.

12. Про внесення змін до деяких законів України щодо регулювання діяльності банків [Електронний ресурс] : закон України від 15.02.2011 № 3024-VI. Режим доступу: http://zakon.nau.ua/doc/?uid=1146.766.2\&nobreak=1.

13. Enhancements to the Basel II framework [Electronic source] / Basel Committee on Banking Supervision // Monetary \& financial stability 2009. - Access mode: http://www.bis.org/publ/bcbs157.htm.

14. Pillar 3 disclosure requirements for remuneration [Electronic source] / Basel Committee on Banking Supervision. - 2011. - Access mode: http://www.bis.org/publ/bcbs197.htm.

15. Basel II: International measurement of capital measurement and capital standards [Electronic source] / Basel Committee on Banking Supervision // Monetary \& financial stability - 2004. - Access mode: http://www.bis.org/publ/bcbs107.pdf. 